\title{
横浜市金沢区の港湾部埋立地における直翅目の分布 状況とそれに影響を及ぼす環境要因
}

Environmental Factors Influencing the Habitat of Orthoptera in the Reclaimed Land of the Harbor Area

板川 暢* 片桐由希子** 一八瀬友博*** 大澤 啓志**** 石川 幹子**

Satoru ITAGAWA Yukiko KATAGIRI Tomohiro ICHINOSE Satoshi OSAWA

Mikiko ISHIKAWA

Abstract : A study was conducted on Orthoptera (Acrididae, Tettigoniidae, Gryllidae) in 56 sites of reclaimed land of Kanazawa District, Yokohama City, Kanagawa Prefecture through May to October of 2008. 28 species and 1941 individuals were recorded during this study. By using TWINSPAN and partitioning, classifications of the Orthoptera and study sites were made based on the results of this study. Also we investigated concerning vegetation, soil, distance from original land, and area coverd with vagetation around field as environmental factors. The study sites were sorted into 5 groups and the Orthoptera were sorted into 4 groups by using TWINSPAN. Based on 5 study site groups, partitioning analysis was conducted. Results suggest vegetation height, coverings of evergreens and deciduous trees of middle to high height, and distance from original land are related to Orthoptera inhabitation. However, it has not been clearly understood the distance from original land was selected as explanatory variable. A further verification is necessary because of the possibility that area coverd with vegetation around the field is related was suggested.

Keywords: Orthoptera, City of Yokohama, reclaimed land, height of grass, TWINSPAN, partitioning キーワード：直翅目, 横浜市, 埋立地, 草丈, TWINSPAN, パーティション

\section{1. 研究の背景と目的}

東京湾をはじめとする日本各地の湾岸部では，20 世紀を中心 に工業用地の確保を目的とした埋め立てが行われてきた。工業や 流通を主体とした土地利用が占める中で, 自然環境に関わる土地 利用としては, アメニティの確保を目的とした都市緑地, 工場立 地法に基づく工場緑地が整備されている ${ }^{1)} 。$ 。方で自然環境との 共生が求められる今日の社会において, 都市域においても生物生 息空間の保全と創出が不可欠と考えられるようになった。このた め, 従来行われてきた街路樹の植栽, 都市公園の整備に加え, 生 物生息空間を意識した屋上緑化や河川・港湾護岸の多自然化, 工 場緑地の整備などが積極的に行われてきている。その流れは港湾 部埋立地にも波及してきており, 三番瀬の人工干潟や大井ふ頭の 多自然型護岸整備, 東京港野鳥公園など, 幾つかの例を挙げるこ とができ, 東京都が進めている「海の森」プロジェクトなど, 埋 立地という環境への関心が高まっている。

埋立地は, 全て客土された土壌基盤であり, 当初, 生物の生息 空間とはかけ離れた人工的な空間であったはずである。そこは, 内陸部のような地象・水象・気象, そして生物群集が, 地誌的時 間をかけて相互作用を繰り返してきた自然的な環境基盤は本来望 めない空間である。それが, 地域が持つ潜在的な自然植生の創造 に配慮して植栽された, いわゆる「エコロジー緑化」樹林に代表 されるように, 造成から数十年という時を経る中で, 生物生息空 間としての緑地環境が改変しつつある ${ }^{2), 3)}$ 。東京都や横浜市では, 臨海部の緑地整備を指針として掲げており, 生物の生存基盤とし

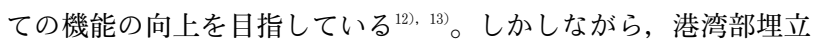
地の人工緑地は, 内陸部の緑地に比へ, 生物生息環境に焦点を当

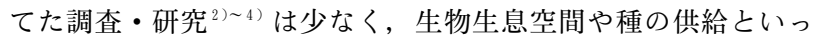
た生態的な機能の把握は未だできていないのが現状である。

一般に昆虫類は, 環境の変化に敏感であり, 人工的に創出され
た緑地空間でも比較的早い段階から移入が見られるため, 港湾部 埋立地のような環境でも生息が十分期待できる。また，生息環境 が種の中で多様化している直翅目は, 緑地構造との関係性が密接 であり ${ }^{18)}$, 直翅目の生息状況から, 緑地の生物生息空間としての 評価を行うことができると考えられるためである。都市域の緑地 において直翅目を対象とした既往研究 ${ }^{5), 6)}$ はいくつか見られる が, 個々の緑地が持つ植生の階層構造や要素に注目したものは少 ない。そこで本研究では, 神奈川県横兵市金沢区の金沢地先埋立 地を対象として, 港湾部埋立地の緑地構造と直翅目 (バッ夕類・ キリギリス類・コオロギ類：以下，バッ夕類とする）の生息状況 の関係を明らかにすることを目的とした。

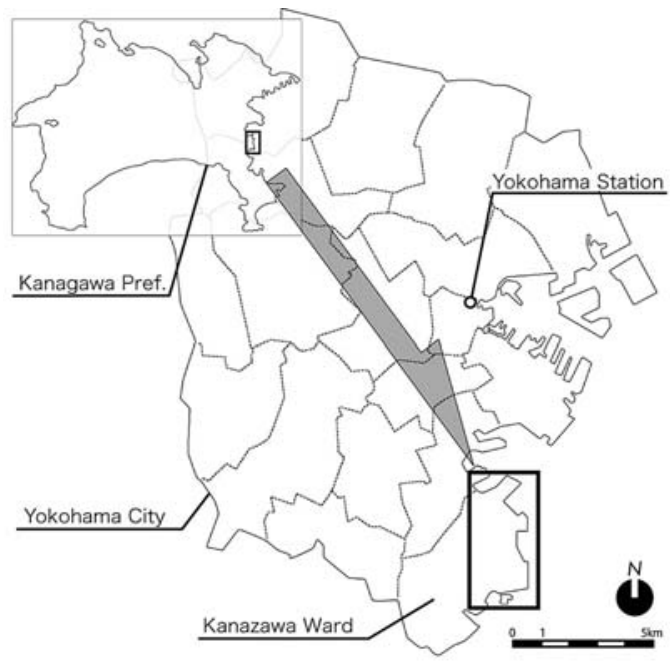

図-1 研究対象地域

"慶應義塾大学大学院政策・メディア研究科 $\quad * *$ 東京大学大学院工学系研究科 ${ }^{* * *}$ 慶應義塾大学環境情報学部

${ }^{* * * *}$ 日本大学 生物資源科学部 


\section{2. 調査地およびに調査方法}

\section{（1）調査地の概要およびに選定}

本研究では, 東京湾沿岸の港湾部の一部である, 神奈川県横浜 市金沢区の埋立地，おおよそ南北に $4 \mathrm{~km}$, 東西に $2 \mathrm{~km}$ に広が る地域を対象として調査を行った（図－1）。対象地域である港 湾部埋立地は，1963 年から造成が始まり，1980 年までにおおよ そが完了した, 造成以後, 概ね 40 年という時間を経ている場所 である。三浦半島の付け根に位置し, 埋め立て地の内側の丘陵地 には金沢自然公園や円海山緑地などに代表されるような良質な緑 地が確保され, また段丘崖線の斜面には自然林・二次林が多く残 されている。金沢区には, 金沢自然公園や海の公園といった大規 模公園をはじめとし, 様々なタイプの緑地の整備が行われており, 公園緑地の面積は横浜市で最大である。対象地域でも, 造成完了 後, 富岡総合公園や長浜公園といった大規模・基幹公園に加え, 街区公園等の緑地の整備が計画的に為されており, 整備後, 30 年以上経過している緑地も多く, 成熟した環境へと姿を変えつつ あると言える。

調查対象とした緑地は, 対象地域内の公園緑地, 防災緑地, 港 湾緑地, 緑道, 道路沿い・中央の植栽帯 (街路樹・中央分離帯) などで，その中から計 15 力所の緑地を調查対象として選定した。 同一の緑地内でも, 微視的に捉えると, 植生の違いや水分条件な どにより, 様々なタイプの環境が混在している。そのため, 対象 とした緑地の中で, 環境要素や条件を考慮して, 合計 57 箇所の 調査地点の選出を行った (図-2)。各調査地点では, $10 \mathrm{~m} \times 10$ $\mathrm{m}$ のコドラートを設定し，その中で調查を行った。 $10 \mathrm{~m} \times 10 \mathrm{~m}$ が破保できない場合は, 適宜幅を変え $100 \mathrm{~m}^{2}$ のコドラートを設定 した。

\section{（2）バッ夕類の調査方法}

本研究では, 五十嵐らの調査 ${ }^{10)}$ を参考に, 調査方法を設定した。

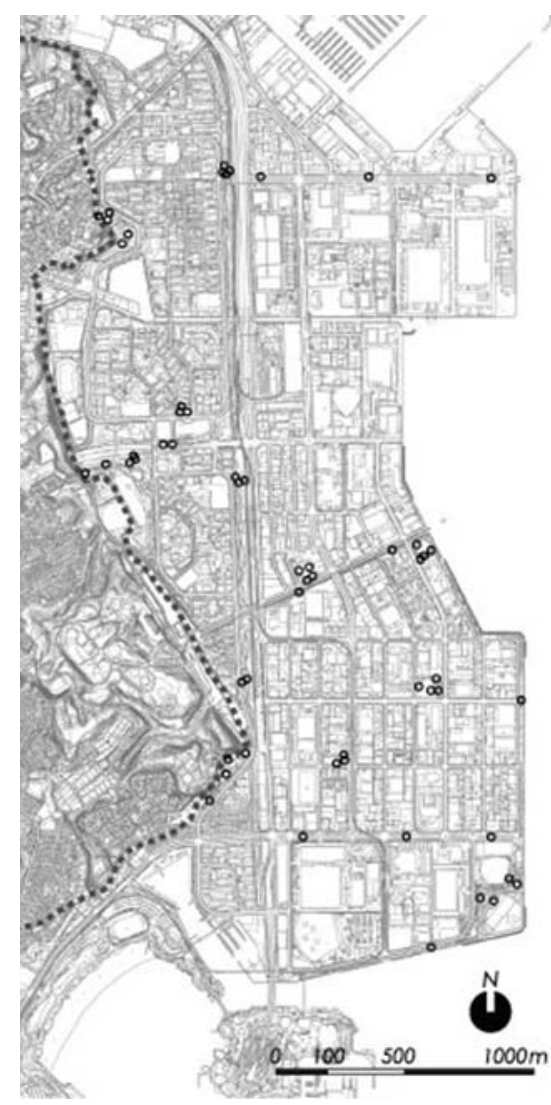

図一 2 調査実施地点

破線：埋立て以前の海岸線（旧海岸線）○：調査地点
調査方法は, 主に 踏み分け法とスイー ピング法を用い, 出現個体数とその 種の記録を行った。 目撃確認法は, 前 述のコドラート内 を重複しないよう に隈なく歩き, 目 撃した種類と個体 数の記録を行った。 目視のみによる同 定が困難な個体に 関しては, 捕獲し て持ち帰り, 図 鑑7)を用いて同定 を行った。捕獲の 際には, 捕虫網 ( $42 \mathrm{~cm}$ 径金属枠) およびに吸虫管な どを用いた。また， 同定が困難な若齢 幼虫, または目撃 した個体で同定が 不十分だとするも のについては, 科 程度までの分類に とどめ, 科名 $\mathrm{SP}$ （近似種）上記録
した。スイーピング法については, 目撃法と同様に, コドラート 内で調査を行った。目撃法による踏査を行ったあとに, 同じコド ラート内を隈なくスイーピングした。スイーピング法には, 上記 の捕蝄と同じものを用いた。目撃法とスイーピング法で, 重複 して確認された個体がいることを考慮し，それぞれで記録された 個体数を比較し, 出現数が多かった方の結果を, その調查地点に おける出現個体数として採用した。このように複数の調査方法を 併用したのは，それぞれの種の個体数をできる限り正確に把握し たかったが，方法によって，各種の捕獲されやすさが異なるため である。

本研究では, 2008 年 5 月から 2008 年 10 月まで, 月に一回の 調査を行った。調査日には，概ね良好な天候の日を数日選び，調 査時間帯は, 目視での調査が可能な日中で, 概ね昆虫類が活発に 活動すると思われる， 9 時から 16 時までとした。

\section{（３）環境要因調査}

(i ) 植生に関する要因

埋め立て地をはじめとする都市部の修景型の植栽地では, 植栽 後間もなく, 定期的な植栽管理が行われているため, 遷移段階の 途中で, 自然林や二次林に見られる階層性とは異なる。そのため, 研究においては緑地の階層区分を, 高木層 ( $5 \mathrm{~m}$ 以上の木本類), 中木層 ( $2 \mathrm{~m}$ 以上 $5 \mathrm{~m}$ 未満の木本類), 低木層 ( $2 \mathrm{~m}$ 未満の木本 類, 灌木・植え込みなど), 草本層（草本類およびに木本類の実 生）之定義した。上記の階層区分において，現地での目視調査に より，それぞれの階層の植被率を $5 \%$ 間隔で記録した。さらに, 木本を対象とした高木層, 中木層, 低木層では, 落葉樹・常緑樹・ 針葉樹それぞれの植被率の算出も行った。

また，草本層については，各調査地点における代表種の被度を 記録した。その情報を基に, シバ，低中茎イネ科，高茎イネ科， ササ, ヨシの被度とこれらすべてを総合したイネ科の被度, さら にオオバコやシロツメクサなどのイネ科以外の人里植物 ${ }^{14)}$ 被度, セイタカアワダチソウやクズなどの大型雑草群の被度, 木本類の 実生の被度とそれ以外の種の被度を総合したものを，同じく $5 \%$ 間隔で記録した。さらに，その調査地における優占種の草丈を， 調査期間を通して, $10 \mathrm{~cm}$ 間隔で記録し, 期間中の平均草丈高と 最高時の草丈高を算出した。

落ち葉や枯れ枝, 枯れ草などで構成されるリターの被度を, 同 じく $5 \%$ 間隔で記録した。さらに, リターの積もっている厚さも 記録した。腐葉土が形成されている地点では, 腐植が始まってい ないリター層の厚さを記録した。

\section{(ii）その他の要因}

各調査地点における, 土壤水分による DC 電圧およびに土壌硬 度を計測した。両項目とも，8回ずつ計測し，その平均を記録し た。計測の際には, コドラートの中心を通る線を引き, その線上 に等間隔に 8 点を設けた。DC 電圧の計測には, ウイジン社製 UIZ3635 プレヒート付き電圧ロガーを使用した。降雨による計 測值への影響を軽減するために，前日までに 3 日以上降雨がない 日を選択した。また, 土壌硬度の計測は, 藤原製作所製の土壌硬 度計(山中式)を用い，土壌水分の計測日と同じ日に実施した。

先述のように, 本研究における調査地域は丘陵地に広範囲の緑 地が残されていることから, 埋立て以前からの陸地にあたる地域 が, 本来の生物生息空間や種の供給機能を果たしていると考えら れる。そのため, 旧海岸線からの距離が, 埋め立て地への種の供 給と関係していると予測した。国土地理院発行の数值地図 25000 （土地条件）を基に, 1947 年撮影の航空写真を参照しながら, 埋 め立て以前の陸地のポリゴンデータを作成した。このポリゴンと 調査地点との直交距離を算出し, 旧海岸線からの距離とした。

さらに, マトリクスの質の指標として, 調查地点から $50 \mathrm{~m}$, $100 \mathrm{~m}$ の周囲の緑被地面積を算出した。周辺環境の樹木被覆率, 
表 -1 確認種の種名と学名

\begin{tabular}{|c|c|}
\hline 和名 (Japanese name) & 学名 (Scientific name) \\
\hline \multicolumn{2}{|c|}{ ・コロギス科（Family Gryllacrididae Blanchard） } \\
\hline コロギス & Prosopogryllacrisjaponica \\
\hline \multicolumn{2}{|c|}{ ・キリギリス科（Family Tettigoniidae Krauss） } \\
\hline ヤプキリ & Tettigonia orientalis Uvarov \\
\hline ヒメギス & Eobiana engelhandti subtropica \\
\hline クサキリ & Ruspolica lineosa \\
\hline クビキリギス & Euconocephahus varius \\
\hline ホシササキリ & Conocephalus maculatus \\
\hline ウスイロササキリ & Conocephalus chinensis \\
\hline ササキリ & Conocephalus melaemus \\
\hline \multicolumn{2}{|c|}{ ・ツユムシ科（Family Phaneropteridae Burmeister） } \\
\hline ツユムシ & Phaneroptera falcata \\
\hline セスジツユムシ & Ducetiajaponica \\
\hline \multicolumn{2}{|c|}{ ・コオロキ科（Family Grylloidea Laicharting ） } \\
\hline イエコオロギ & Acheta domesticus \\
\hline エンマコオロギ & Telegyyllus infernails \\
\hline モリオカメコオロギ & Loxoblemmus sylvestris \\
\hline ツヅレサセコオロギ & Velarifictorus micado \\
\hline \multicolumn{2}{|c|}{ •マツムジ科 (Family Eneopteridae Gorochov ) } \\
\hline アオマツムシ & Truljalia hibinonis \\
\hline \multicolumn{2}{|c|}{ ・ヒバリモドキ科（Family Trigonidiidae Saussure ） } \\
\hline マダラスズ & Dianemobius nigrofasciatus \\
\hline シバスズ & Polionemobius mikado \\
\hline \multicolumn{2}{|c|}{ •・ヒシバッタ科 ( Family Tetrigidae Rambur ) } \\
\hline ハネナガヒシバッタ & Euparatettix insularis Bey-Bienko \\
\hline ハラヒシバッタ & Tetrixjaponica \\
\hline \multicolumn{2}{|c|}{ ・オンブバッタ科 ( Family Pyrgomorphidae Brunner von Wattenwyl) } \\
\hline オンブバッタ & Atractomorpha lata \\
\hline \multicolumn{2}{|c|}{ ・バッ夕科 (Family Acrididac MacLeay ) } \\
\hline ツチイナゴ & Patanga japonica \\
\hline コバネイナゴ & Oxya yezoensis Shiraki \\
\hline ショウリョウバッタ & Acrida cinerea \\
\hline ショウリョウバッタモドキ & Gonista bicolor \\
\hline トノサマバッタ & Locusta migratoria \\
\hline クルマバッタ & Gastrimargus marmoratus \\
\hline クルマバッタモドキ & Oedaleus infernalis \\
\hline イボバッ夕 & Trilophidiajaponica Saussure \\
\hline
\end{tabular}

植被率が鳥類の分布に影響しているとされ ${ }^{15)},{ }^{16)}$, バッ夕類につい ても検証を行うために, 緑被率を説明変数として取り入れること にした。算出には, 横浜市から借用した, 第 7 次緑地環境診断調 查により抽出された緑被地デー夕を使用した。各調査地点から, $50 \mathrm{~m}$ と $100 \mathrm{~m}$ のバッファを発生させ, その中に含まれる緑被地の 面積をそれぞれ算出した。旧海岸線からの距離と周囲の緑被地面 積の算出には, ESRI 社の ArcGIS9.3 を用いた。

\section{(4) 分析方法}

TWINSPAN (Two-Way Indicator Species Analysis) を用い て, 各調査地点で記録された直翅目の種組成に基づき, 対象地点 と種の分類を行った。一地点もしくは同一緑地内でのみしか記録 されていない種，およびに正確な同定ができず，近似種としたも のは分析から外した。また, 調査期間を通して, 直翅目の出現が 確認されなかった 1 地点を除き, 56 地点・23 種を用いて分析を 行った。pseudospecies cut levelには, それぞれの種の累積出現 個体数を用い, cut level を 0,5,20,50に変更した。これは, 出現 した個体数が 100 個体を超える地点がある一方で, 極端に出現数 が少ない地点もあったためである。分析には, MjM 社の PCORD for win ver.5.20を使用した。

TWINSPAN により分類された調査地点群が, どのような環 境要因の影響を受けているのかを明らかにするために，パーティ ションを行った。パーティションは，データマイニング手法のひ
とつで，X 值と Y 值の関係に従ってデー夕を再帰的に分岐させ, パーティションツリーを作成する手法である。Y の值を最もよ く予測できるような X の值のグループを見つけるのが目的で, 考えられる限りの分岐とグループ化が実行される。生態学の分野 で用いられている分類・回帰樹木と同様の手法であり, シバ草地 の草量に与える要因の解析 ${ }^{20)}$ などにも用いられている。説明変数 に用いた環境要因は, 高木被度, 高木常緑被度, 高木落葉被度, 中木被度, 中木常緑被度, 中木落葉被度, 高中木被度, 高中木常 緑被度, 高中木落葉被度, 低木被度, 低木常緑被度, 低木落葉被 度, 草本被度, それぞれの代表種群の被度, 平均草丈, 最高草丈, リター被度, リ夕ーの厚さ, 土㙵硬度, 土㙵水分による DC 電圧, およびに旧海岸線からの距離, $50 \mathrm{~m}$ 周囲と $100 \mathrm{~m}$ 周囲それぞれ の緑被地面積の 32 項目である。今回は, 分岐等計量を最大化し て分割を行った。分析には, SAS 社の JMP ver.8.0.1を用いた。

\section{3. 結果}

\section{(1) 調査結果}

調查地全地点で，調査期間中を通して記録された出現個体数の 総計は 1941 個体で，月ごとの内訳は， 5 月が 102 個体， 6 月が 347 個体， 7 月が 546 個体， 8 月が 374 個体， 9 月が 353 個体, 10 月が 219 個体であった。

確認種数は, 28 種の直翅目が確認された。神奈川県レッドデー タブック ${ }^{11}$ に記載されている種としては，要注意種に指定されて いるショウリョウバッタモドキが確認された。最も多くの種が確 認されたのは 9 月の 27 種で, 最も少なかったのは 5 月の 5 種で あった。出現が確認された種は，表－1に示した。

\section{(2) TWINSPAN}

調查地点の分類，およびに出現種の分類には，上位 3 段階まで の分割結果を採用した。TWINSPAN の結果, 調查地点は 5 つ

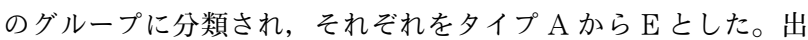
現種は 4 つのグループに分類された（図一 3 )。

タイプ A とタイプ E はそれぞれ 2 力所で構成されるグループ で，ともに道路の中央に設けられた植栽帯と街区公園に設置した 調査地点で構成された。タイプ A の二カ所に共通して出現した 種はイボバッタで, タイプ E の二カ所に共通して出現した種は シバスズであった。タイプ B は, 緑道の脇の草地や公園内の広 場などで構成され，此較的に人の立ち入りや利用頻度が高い草地 で，高木層の被度が高い地点も多く含まれた。タイプ C は，人 の立ち入りが少ないと思われる中央分離帯内の植栽帯や, 樹木之 草本亡の階層が形成されている草地などで構成されている。タイ プ D に分類された調查地点は, 草本層の被度が低く, 防災緑地 や街区公園の緩衝樹林で構成された。

(3) パーティション

パーティションの結果を図ー 4 に示す。10 カ所の調査地点が 誤判別され, 誤判別率は $17.9 \%$, 累積寄与率は $79.1 \%$ あっった。

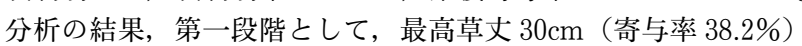
を基準に 2 つに分割された。タイプ $\mathrm{D}$ とタイプ $\mathrm{C}$ の 1 カ所を除 くすべてが, 最高草丈が $30 \mathrm{~cm}$ 以上のグループに区分され, 夕イ プ $\mathrm{E}$ はすべて $30 \mathrm{~cm}$ 未満のグループに区分された。次に，最高 草丈の低いグループが，高中木常緑の被度 50\%（寄与率 17.7\%） を境に分割され，被度 $50 \%$ 以上のグループはタイプ E と区分さ れ，50\%未満のグループはタイプ B と区分された。しかし，夕 イプ E と区分されたグループにタイプ B の 1 カ所, タイプ B に 区分されたグループにタイプ A とタイプ C の 1 カ所ずつが詋判 別された。このグループに区分されたタイプ B は 14 カ所中 5 カ 所である。最高草丈が $80 \mathrm{~cm}$ 未満のグループは, 旧海岸線からの 距離が 508.32m（寄与率 14.8\%）を境に二つに分かれ，旧海岸線 から近いグループはタイプ C と区分され，タイプ C の 9 カ所と 


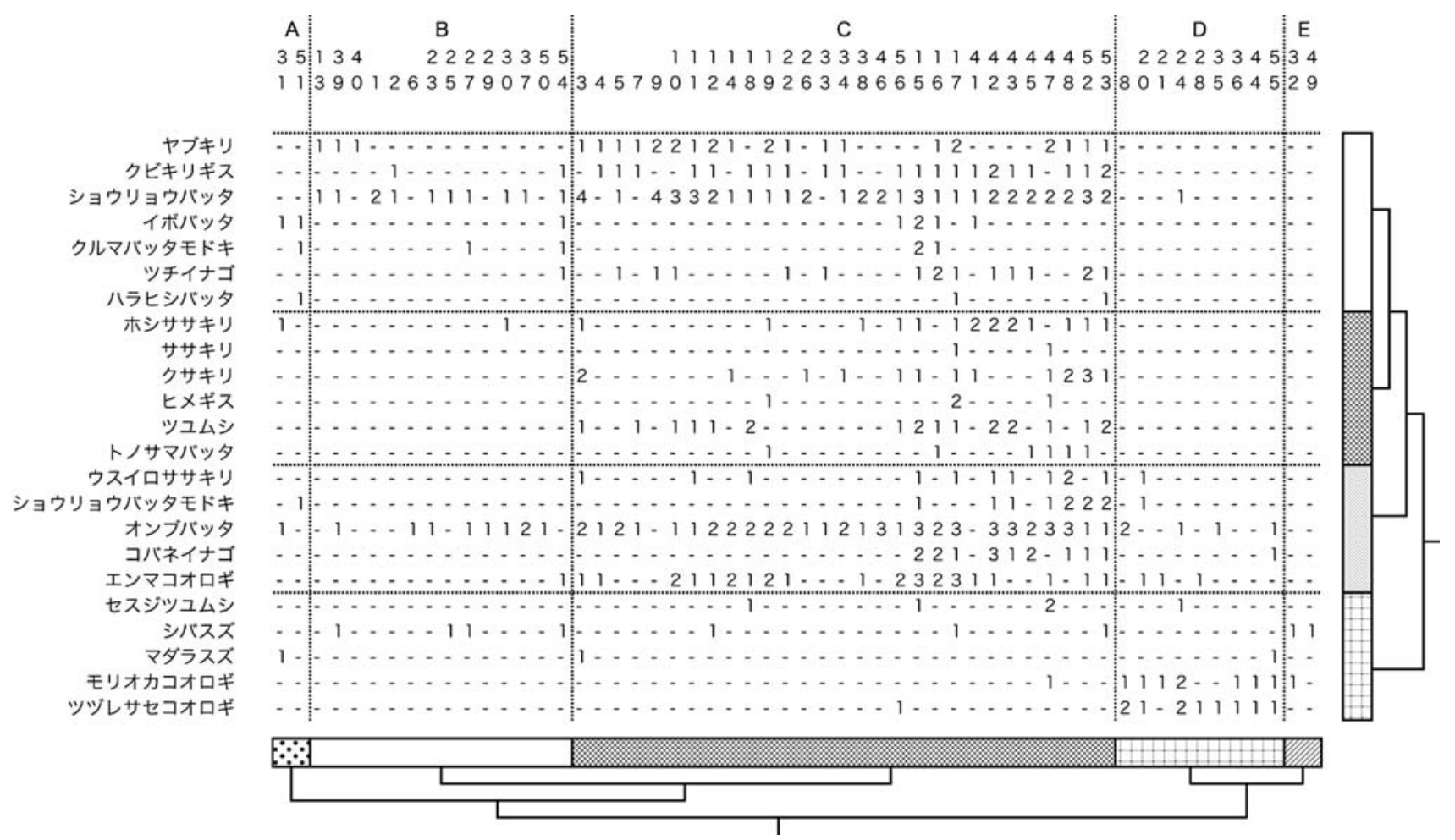

図ー 3 TWINSPAN の結果

左の列は種名, 上の数字は調査地点番号を示す。今回の分析では, pseudospecies cut level にそれぞれの種の累積出現個体数を用いた。図中の数字は, 累積個体数を $1: 1-5$ 個体， $2: 6-20$ 個体， $3: 21-50$ 個体， $4: 51$ 個体以上の 4 段階で示したものである。

タイプ Fの 1 カ所がこのグループに該当した。旧海岸線から離 れているグループは，高・中木層の落葉樹による被度が $25 \%$ （寄与率 $8.52 \%$ ）を基準に分割され，被度が高いグループがタイ プ $\mathrm{B}$ ，低いグループがタイプ C と区分された。

以上から, タイプ D の調查地点は最高時の草丈が低く, 高木・ 中木層の常緑樹の被度が高いという特徴があることが示された。 一方で, タイプ C の調查地点は, 草丈が高く, 旧海岸線からの 距離が近いか, 離れていても, 高木・中木層の落葉樹の被度が低 いという傾向が示された。また, タイプ B は高木・中木層常緑 樹の被度が高い, 屯しくは, 旧海岸線から離れていて, 高木・中 木層落葉樹の被度が高いという傾向があることが示された。タイ プ $\mathrm{E}$ は，草丈が高い調查地点である傾向が読み取れるが，タイ プ A およびにタイプ E に関しては, 区分された調査地点が 2 力 所ずつで，それぞれが異なるグループに分散したため, 今回の結 果からは，はっきりとした特徵が確認できなかった。

\section{4. 考察}

バッ夕類の生息分布とそれを取り巻く環境亡の関係は, 植生 ${ }^{17)}$ をはじめとして，これまでの研究で明らかにされてきている。し かし，それぞれの研究では個々の要因について言及されているも のの, 幅広い要因を基にバッ夕類の生息との対応を見ているもの は少ない。本研究では, バッ夕類の分布に影響している環境要因 として, 草本層の草丈, 樹木の被度, 埋め立て以前の陸地からの 距離が選択された。

\section{(1) 草丈}

今回の分析では, 分割の第一段階で, 最高時の草丈高 $30 \mathrm{~cm}$ を 基準に区分された。最高草丈が $30 \mathrm{~cm}$ 以上のグループに出現して いるホシササキリやクサキリは，比較的浅く明るい草地を好み， 15-20 cm 以上の草地に生息するとされ7), 今回の分析結果と大方 合致する。また, 既往の知見 ${ }^{10), 18)}$ でも, 草丈高がバッ夕類の生
息に関与していることが指摘されている。こうした中で，最高時 の草丈高が選択された要因を考察する。なお，後述するように， あくまで管理強度がバッ夕類の生息に関与すると考えられ，その 指標として本調査では草丈高 $30 \mathrm{~cm}$ が区分点と判定された。

まず 1 点目として, 草丈高が高くなることによって, 微視的な 生息空間として選択の幅が広がることである。バッ夕類は種によっ て定位位置が異なり, それは地上高と気温の影響を受けていると され ${ }^{5}$ ，また，クサキリは成長過程で，葉の先と根に近い茎の低 い部位を食べ分けるとされる7)。こうしたことから，草丈高が増 減することによって, 気温や食相などの要素により, 微視的な生 息空間の多様度も変化していることが考えられる。既往の知見は ないものの，微視的な生息環境に変化を及ぼす要因として，草本 の密度や照度, 湿度なども考えられるため, 今後の検証が求めら れる。2 点目は, 人為的な影響である。飯山らが行った調査 ${ }^{19)}$ によると, 草刈り回数が増えるとともに, 最大植生高は減少する とされる。また, 最高時でも草丈が $30 \mathrm{~cm}$ に満たない地点では, オオバコやシロツメクサ，スズメノカタビラ，メヒシバなど，土 地の擋乱や植生の破壊が大小，不規則的に加わる土地を生活の場 とする種 ${ }^{14)}$ が優占していた。すなわち，こうした草丈の最高長 が $30 \mathrm{~cm}$ に満たない草地では, 草刚りの頻度や踏圧などの人為的 な影響が大きいことが考えられる。タイプ Cに出現したウスイ ロササキリ，ツユムシ，クビキリギスなどは，草本の茎中に産卵 する7) とされる。こうした産卵形態の違いから, 定着しない種が あるのではないかと考えられる。特に，クビキリギスは春から初 夏にかけて産卵を行うため, 人為的圧力の影響は大きいと考えら れる。市街地近郊の公園緑地で昆虫類を対象に行われた研究 ${ }^{22}$ では, 直翅目の生息には草刈りなどの管理による影響は少ないと 指摘されているものの，検証の余地があると言えるだろう。

\section{(2) 樹木の被度}

今回の結果から，樹木の被度に関する二つの項目が，バッ夕類 


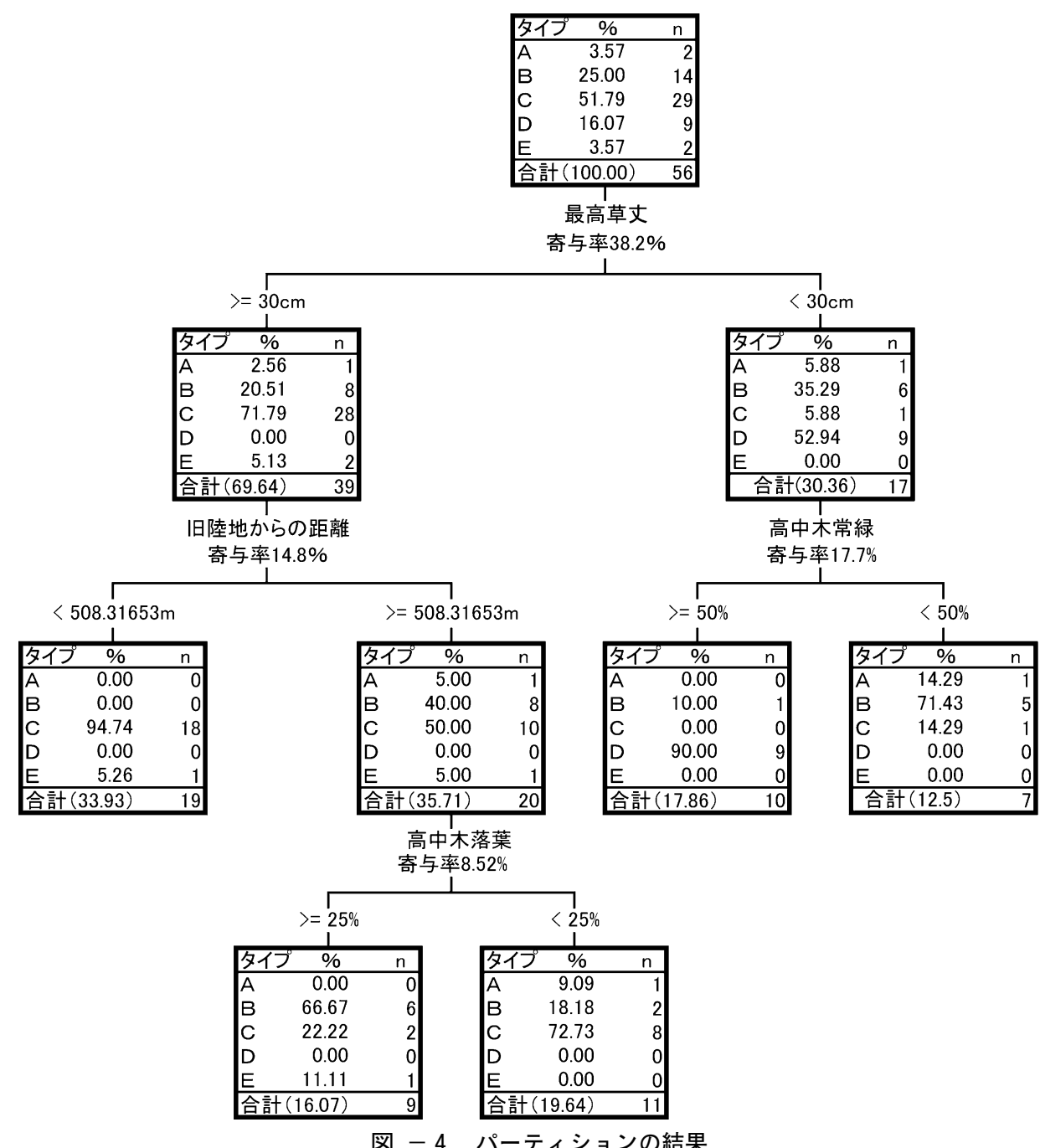

TWINSPAN によって分類された調査地点群をタイプ A-E としている。 $\mathrm{n}$ は調査地点数，\%はそのグループに含 まれる各タイプの調査地点数の全体の割合を示す。分岐点の上に示したのは, その分岐で選択された説明変数と 寄与率，分岐の下に示したのが，その分岐で採用された説明変数の閾値である。

の生息に関わる要因として選択された。今回の結果から, 高・中 木層の常緑樹による被度, およびに落葉樹の被度が, バッ夕類種 の分布に影響をおよぼしていることを示すことができた。腐食性 昆虫, 粪食性昆虫 ${ }^{23)}$, ${ }^{24)}$ や鳥類 ${ }^{15,}$, 16) に関する研究では, 緑地の階 層構造が生物群集の組成に影響を及ぼしているとされている。島 田ら ${ }^{23)}$ は, 高 ・ 中木層の植栽密度と林層形態が腐食性昆虫, 糞食 性昆虫の生息に影響を及ぼしていると報告しており, 今回の結果 とも一致する。

タイプ D はすべて, 高・中木層の常緑樹の被度が $50 \%$ 以上の 地点であることが明らかになった。タイプ D に分類された調査 地点の多くは, 草本層の被度が低く, 防災緑地の樹林地や街区公 園などの緩衝樹林で構成される。タイプ D に特徴的に出現した 種であるモリオカメコオロギの仲間は, 落ち葉などの下に生息す るとされ7)，分析の結果とも対応していると言える。

草丈が高い調査地点群では, 高・中木層の落葉樹の被度が影響 していることが明らかになった。タイプ B に比べ, 出現種数が 多かったタイプ C の方が, 被度の低いグループに選択されたこ とから, バッ夕類の多様性には, 高・中木層の樹林の被度が高す ぎることは, 負に働くことが窺える。タイプ B およびにタイプ C は，樹林地ではなく，一般的に言われる草地で，両者の低木層・ 草本層の被度に大きな差はないことから，バッ夕類の生息には, 緑地の階層性, 特に草地環境における木本層の存在が, 群集の組
成に影響していることが示唆され る。バッ夕類の微視的生息場所の 選択に気温が関係している ${ }^{5)}$ との 指摘もあることから，木本層が及 ぼす影響として，ニッチとしての 生息場所としての機能だけでなく, トンボ類 ${ }^{9)}$ で指摘されているよう な, 緑陰が存在することによる気 温の変化が考えられる。

二つの選択された要因は, 高木 層, 中木層をそれぞれ分けた被度 も説明変数として取り入れてあっ たのにも関わらず，ともに高・中 木層合わせてのものであった。こ のことから，バッ夕類にとって， 中木層と高木層という区分は有意 ではないことが推察される。

\section{（３）旧海岸線からの距離}

タイプ $\mathrm{B}$ とタプ C で構成さ れる最高草丈が $30 \mathrm{~cm}$ 以上の調查 地点群は, 旧海岸線からの距離で 分割され, 旧海岸線に近いグルー プにタイプCの多くが区分され た。草丈の高さが同じ草地環境の 場合, 旧海岸線から近い地点が, 個体数およびに種数が多いことが わかった。旧海岸線からの距離が, 環境要因として選択された要因を 考察する。旧海岸線からの距離と $50 \mathrm{~m}$ およびに $100 \mathrm{~m}$ 周囲の緑被 地面積の二変量の関係を見ると, 旧海岸線から距離が離れた地点ほ ど, 周囲の緑被地面積が小さいこ とから, 緑被地面積がバッ夕類の 生息に関与していることも考えら れる。今回の結果では周囲の緑被

地は選択されなかったが，これは今回扱った緑被地が，いわゆる 緑地全般をひとまとめにして扱っていることに起因すると考えら れる。緑被地と言っても, それぞれが様々な環境要因や条件を有 しており, 均質なものではないからである。そのため, 緑被地を さらに細分化し，検証を行う必要があるだろう。

一方で, $500 \mathrm{~m}$ という距離は, 調査地域に隣接した埋立て以前 からの陸地の本来の生物生息空間から，造成以後の数十年という 期間に，バッ夕類の移入が及ぶ範囲であることも考えられる。す なわち, 旧海岸線からの距離という変数は, 種の供給源からの距 離を代弁している可能性がある。都市に造成された緑地における 鳥類の調査 ${ }^{26)}$ では, 種の定着には約 10 年必要とされ, 造成後数 年間の記録種数は増加傾向にあるとされている。鳥類に比べ，バッ 夕類の移動能力が低く, 当調査地の殆どは生物の定着を目的とし たものではないものの，長い時間を経て，バッ夕類の生息空間と して徐々に成熟し, 移入が進んできていることが考えられる。な お， $500 \mathrm{~m}$ という值自体はあくまでパーティションによる区分点 として示されたものであり, 本地区で「数十年の期間で定着でき たのが概ね数 $100 \mathrm{~m}$ までであること」が本研究での知見といえる。 仮に, 埋立て以前からの陸地の緑地が種の供給機能を担っている 場合, さらなる種の移入を促進させるためには, 計画的に緑地を 連続させていくようなエコロジカル・ネットワークの形成が求め られる。また, 当調査地域の内部には, 種の供給源が存在してい 
るとは言えないため, 生息環境が一定規模以上に集積した種の供 給源となるような緑地パッチの創出が課題であると言える。

\section{（4）その他の要因}

五十嵐ら $(1983)^{10)}$ は, 草丈, 土壌湿度など, 草地の状態を, 指標である直翅目の出現から把握できるとした。今回, 草丈では 同様の結果が得られたものの, 土壌水分による DC 電圧に関して は, 説明変数として選択されなかった。当調查地域では, いわゆ る湿地や砂碟地, 裸地といった環境が存在しなかったため, 土袞 水分による DC 電圧に目立った差は見られなかったことが, 説明 変数として選択されなかった理由として考えられる。

バッ夕類群集組成には, 植生タイプ17) とその構成 ${ }^{18)}$ が関係して いることを指摘しているものの, 今回の結果では植生タイプに関 する項目は選択されなかった。また, タイプ D の標徴種, リター の被度は選択されなかったが, これは人為的な管理によって, 落 ち葉の除去や移動がされていることによって, 一定の值を得られ なかったことが考えられる。今後の課題として, 管理作業などの 人為的な圧力を定量化し, それがバッ夕類によ゙ういった影響を及 ぼしているのかを明らかにすることが挙げられる。

\section{5.まとめ}

本研究では, バッ夕類の分布に, 管理強度の指標としての最高 時の草丈, 中・高木層の常緑樹およびに落葉樹の被度, およびに 埋め立て以前の陸地からの距離が関与しているという, 新たな知 見を示すことができた。草丈の高さを示すことで, 草地の維持管 理に関する指針を示すことができた。また, 緑地の階層性につい ての情報は, 今後の緑地整備・創出に向けた, ひとつの指針を提 示できた。

また，生物情報の乏しかった埋め立て地において，生息状沉に 関する情報を集めることができたことで，埋め立て地という人工 的な環境が, 生物生息空間として十分に機能していることを明ら かにできた。中島ら ${ }^{2)}$ の研究では, 湾岸部の人工樹林において, 施工竣工 18 年目で階層構造が形成されつつあり, セミ類や甲虫 類をはじめとした昆虫類の生物生息空間として機能し始めている と指摘している。今回の調查でも, 施工竣工後 26 年が経過して いる金沢緑地の樹林では, コオロギ類の出現を確認できたととも に，わずかに形成された下層植生で，コバネイナゴやオンブバッ 夕が記録されており, 将来的に草本や林縁の灌木などの下層植生 が形成された場合には，新たな種の定着も期待できるだろう。

一方で, 以前の陸域からの距離に関しては, はっきりとした選 択要因を読み取ることはできなかった。今後, 当調査地域の生物 生息空間としての機能性を向上させていくためには, エコロジカ ル・ネットワークの形成が欠かせない。今後, 周辺の環境の質, 緑地の連結性などを含めた具体的な要因の解明に努めて行きたい。

\section{謝辞：}

調査にご協力頂いた佐々木恵子氏, 論文執筆にご助言・ご協力 頂いた皆椂に御礼申し上げる。本研究は, 建設技術研究開発費補 助金「東京ベイエリアにおける水と緑のネットワーク形成に関す る研究」(研究代表者：石川幹子）の一環として行ったものであ る。

\section{引用文献}

1）大塚高雄（2007）：東京臨海部の緑地計画：都市計画 56(5), 31-36

2 ) 中島敦司 - 養父志乃夫 - 山田宏之 - 駒走裕之（1998）：湾岸 工場地での「エコロジー緑化」植栽地における施工 18年目 の林分構造 : ランドスケープ研究 61(5), 505-510

3 ) 中島敦司・中尾史郎・養父志乃夫 - 山田宏之（2000）：人工
島の環境保全緑地のもつ昆虫生息場所機能 : ランドスケープ 研究 63(5), 509-514

4 ）片桐由希子・大澤啓志・山下英也・石川幹子（2008）：川崎 臨海工業地帯における緑地環境の特性に関する研究 : 都市計 画論文集 43(3)，577-582

5 ）秦裕史・中尾史郎・養父志乃夫 - 中島敦司 - 山田宏之 （2003）：公園緑地におけるバッ夕類の微視的生息場所選択： ランドスケープ研究 66(5), 607-612

6 ）養父志乃夫 - 山田宏之 - 中島敦司 - 中尾史郎・松本勝正 （2001）：大規模市街地内から郊外地にかけてのバッ夕類の 生息密度の変化について : ランドスケープ研究 64(5), 595600

7 ）日本直翅類学会編（2006）：バッタ・コオロギ・キリギリス大 図鑑：北海道大学出版会, $687 \mathrm{pp}$

8 ）国土交通省：航空写真画像情報所在検索・案内システム $<$ http://airphoto.gis.go.jp/aplis/Agreement.jsp>, 2009. 8.15 更新, 2009.8 .22 参照

9 ) Micheal J.Samways • Nicholas S.Steytler (1996) : Dorag onfly (Odonada) distribution patterns in urban and forest landscapes, and recommendations for riparian managem ent: Biorogical Conservation, 78, 279-288

10）五十嵐良造・川鍋祐夫・酒井博（1983）：直翅目昆虫之雑草 を指標とした草地の生態区分：草地試研報 $25,1-17$

11）神奈川県：神奈川県レッドデータブック 2006 WEB 版：eTANZAWA <http://www.e-tanzawa.jp/>, 2009.9.18 更新, 2009.9.15 参照

12）東京都（2000）：緑の東京計画：東京都環境局， $122 \mathrm{pp}$

13）横浜市（2007）：横浜市水と緑の基本計画：横浜市環境創造 局総合企画部環境政策課, $236 \mathrm{pp}$

14）沼田眞・岩瀬徹（2002）：日本の植生：株式会社講談社, $313 \mathrm{pp}$

15）鵜川健也・加藤和弘（2005）：都市域の中・大規模樹林地に おける鳥類の種多様性と立地環境との関係：ランドスケープ 研究 69(5), 533-536

16）鵜川健也・加藤和弘（2006）：都市域の樹林地および樹林地 を取り巻く空間の環境条件と鳥類群集との関係：ランドスケー プ研究 70(5), 487-490

17) W.P.Kemp • S.J.Hervey • K.M.O'Neill (1990) : Patterns of vegetation and grasshopper community composition : Oecologia83, 299-308

18) WALTER WETTSTEIN - BERNHARD SCMID (1999) : Conservation of arthropod diversity in montane wetlands: effect of altitude, habitat quality and habitat fragmentation on butterflies and grasshoppers : Journal of Applied Ecology36, 363-373

19）飯山直樹・鎌田磨人・中川恵美子・中越信和（2002）：棚田 畦畔の構造および草刈りの差異が植物群落に及ぼす影響：ラ ンドスケープ研究 65(5), 579-584

20）富松元・板野志郎・堤道生（2008）：ライジングプレートメー 夕を用いたシバ優占草地の草量推定に影響を与える要因の解 析：日本草地学会誌 54(2), 134-140

21）橋本啓史・中村進・長谷川美奈子・夏原 由博・森本幸裕： 復元型ビオトープにおける鳥類相の初期遷移：ランドスケー プ研究 68(5), 559-562

22）島田正文・丸田頼一（1988）：市街地近郊の二次林を主体と した公園緑地における昆虫類の生息に関する研究：造園雑誌 51(4), 219-227

23）島田正文・高橋徹雄・丸田頼一（1991）：公園緑地における 昆虫類の生息環境に関する研究：造園雑誌 54(5), 287-292

24）島田正文（1985）：市街地における公園緑地の昆虫生息に関 する研究：造園雑誌 48(5), 187-192 